\title{
Classification of Proteases in Antarctic Krill
}

\author{
Kimio Nishimura, Yukio Kawamura, Teruyoshi Matoba \\ and Daizo YonEzAWA* \\ Research Institute for Food Science, Kyoto University, \\ Uji, Kyoto 611, Japan
}

Received May 9, 1983

\begin{abstract}
The species of endogenous proteases in Antarctic krill, Euphausia superba, were investigated using the homogenate of krill and the active fractions after gel filtration of the homogenate as to the following criteria: Substrate specificity (benzyloxycarbonyl (Z)-Phe-Ala, Z-Glu-Tyr, hippuryl-Arg, hippuryl-Phe, benzoyl Arg- $p$-nitroanilide, Leu- $p$-nitroanilide, ${ }^{14} \mathrm{C}$-hemoglobin), sensitivity to protease inhibitors (diisopropyl fluorophosphate, iodoacetamide, EDTA, soybean trypsin inhibitor and pepstatin), molecular weight and isoelectric point.

From the experimental results, we found that the carboxypeptidase A and B, aminopeptidase, trypsin and cathepsin A types of proteases were present in krill.
\end{abstract}

Antarctic krill, Euphausia superba, is one of the most promising protein resources of the future from the standpoints of the nutritive value $^{1 \sim 6)}$ and the amount available. ${ }^{3,5)}$ However, the most undesirable problem in utilizing krill as a food is the autolysis of krill proteins after catching or thawing of the frozen stored krill. ${ }^{4,5,7} \sim 9$ )

In the previous paper, ${ }^{10}$ ) we showed that the autolysis of krill protein was very rapid and extensive, and this rapid autolysis was due to the endogenous proteases. However, it has not been clear what kinds of proteases are present in krill, although several reports concerning krill proteases have been published. ${ }^{11 \sim 17)}$ Seki et al. ${ }^{13)}$ reported the presence of some trypsinlike proteases. Kimoto et al. ${ }^{16)}$ prepared the acid proteases. Nagahisa et $a .^{12)}$ suggested that some types of proteases were contained in krill from an experiment on the activities using casein as the substrate.

In the present investigation, the species of endogenous proteases in krill were clarified from the following criteria: Substrate speci- ficity, sensitivity to protease inhibitors, molecular weight and isoelectric point.

\section{MATERIALS AND METHODS}

Materials. Antarctic krill was caught in September, 1977 , and frozen at $-20^{\circ} \mathrm{C}$ within $2 \sim 3 \mathrm{hr}$ after catching. It was delivered to the laboratory in March, 1978, and stored at $-80^{\circ} \mathrm{C}$ untill used. Z-Glu-Tyr, Bz-Arg-pNA, Leu-pNA, Hipp-Phe, Hipp-Arg, pepstatin, and IAA were obtained from the Protein Research Foundation, Osaka, and bovine $\mathrm{Hb}$, DFP and STI from Sigma. ZPhe-Ala was prepared according to the method of Sheehan and Hess. ${ }^{18)}{ }^{14} \mathrm{C}-\mathrm{Hb}$ was synthesized according to the method of Williams and Lin. ${ }^{19)}$ Sephadex G-150 was purchased from Pharmacia Co. The standard proteins for the molecular weight estimation by gel filtration were $\gamma$-globulin from Povite Co., and BSA, chymotrypsinogen and myoglobin from Boehringer Co. Ampholine $(\mathrm{pH}$ $3 \sim 10)$ was obtained from LKB Products Co.

Assay of the protease activity. Hydrolase activities for ZPhe-Ala, Z-Glu-Tyr, Hipp-Phe and Hipp-Arg were determined by the colorimetric ninhydrin procedure of Moore and Stein. ${ }^{20)}$ Hydrolase activities for Bz-Arg-pNA and Leu-pNA were determined by the method of Ward. ${ }^{21)} \mathrm{A}$ reaction mixture $(1 \mathrm{ml})$ contained substrate, an appropriate amount of enzyme and $0.1 \mathrm{M}$ acetate buffer, $\mathrm{pH} 5.0$, in

* Present address: Department of Food Science, Faculty of Home Economics, Mukogawa Women's University, Nishinomiya, Hyogo 633, Japan.

Abbreviations: BSA, bovine serum albumin; Bz, benzoyl; Cpase, carboxypeptidase; DFP, diisopropyl fluorophosphate; $\mathrm{Hb}$, hemoglobin; Hipp, hippuryl; IAA, iodoacetamide; MW, molecular weight; pNA, p-nitroanilide; STI, soybean trypsin inhibitor; TCA, trichloroacetic acid; Z, benzyloxycarbonyl. 
the presence or absence of $0.6 \mathrm{M} \mathrm{KCl}$ or $0.1 \mathrm{M}$ Tris- $\mathrm{HCl}$ buffer, $\mathrm{pH} 8.0$, in the presence or absence of $0.1 \mathrm{M} \mathrm{KCl}$. The concentration of each substrate was $3.3 \mathrm{~mm}$ for Z-PheAla, Z-Glu-Tyr, Hipp-Phe and Hipp-Arg, $0.75 \mathrm{~mm}$ for BzArg-pNA and $1 \mathrm{~mm}$ for Leu-pNA. The reaction was performed at $37^{\circ} \mathrm{C}$ for $30 \sim 60 \mathrm{~min}$ and stopped by addition of $1 \mathrm{ml}$ of $10 \%$ TCA. After the resulting precipitated protein was removed by centrifugation, the hydrolase activities were determined in terms of amino acid or $p$ nitroaniline released from each substrate. A reaction mixture $(700 \mu \mathrm{l})$ for the assay of the hydrolase activity on ${ }^{14} \mathrm{C}-\mathrm{Hb}$ consisted of $50 \mu \mathrm{l}$ of ${ }^{14} \mathrm{C}-\mathrm{Hb} \quad(12.5 \mathrm{~g} / \mathrm{ml}$ $120,000 \mathrm{cpm} / \mathrm{ml}), 50 \mu \mathrm{l}$ of enzyme solution and $600 \mu \mathrm{l}$ of $0.1 \mathrm{M}$ acetate buffer, containing $0.6 \mathrm{M} \mathrm{KCl}, \mathrm{pH} 5.0$, or $0.1 \mathrm{M}$ Tris- $\mathrm{HCl}$ buffer, containing $0.1 \mathrm{M} \mathrm{KCl}, \mathrm{pH}$ 8.0. The reaction was performed at $37^{\circ} \mathrm{C}$ for $90 \mathrm{~min}$ and stopped by dipping the test tube in an ice-bath at $0^{\circ} \mathrm{C}$. Then, $50 \mu \mathrm{l}$ of $4 \%$ cold $\mathrm{Hb}$ was added to the reaction mixture followed by addition of $700 \mu \mathrm{l}$ of $10 \%$ TCA. After centrifugation, the radioactivity of the supernatant was determined with a liquid scintillation spectrometer, Packard 3385. The protein content was determined by the method of Lowry et $a .^{22)}$

Preparation of homogenate and crude extract from krill. Frozen krill (whole body) was homogenized at $0^{\circ} \mathrm{C}$ in 5 vol of $0.1 \mathrm{M}$ acetate buffer, $\mathrm{pH} 5.0$, or $0.1 \mathrm{M}$ Tris- $\mathrm{HCl}$ buffer, $\mathrm{pH}$ 8.0. The homogenate was filtered through a gauze. The resulting filtrate was subjected to assaying of protease activity (Table I). Frozen krill (whole body) was also homogenized at $0^{\circ} \mathrm{C}$ in $5 \mathrm{vol}$ of the $\mathrm{pH} 5.0$ buffer containing $0.6 \mathrm{M} \mathrm{KCl}$ or the $\mathrm{pH} 8.0$ buffer containing $0.1 \mathrm{M} \mathrm{KCl}$. The homogenate was centrifuged, and then ammonium sulfate was added to the supernatant to $80 \%$ saturation. The precipitate was dialyzed against the $\mathrm{pH} 5.0$ or 8.0 buffer containing $\mathrm{KCl}$ overnight at $4^{\circ} \mathrm{C}$. After centrifugation, the clear supernatant was concentrated by ultrafiltration. The resulting concentrate (crude extract) was subjected to gel filtration (Figs. 1 and 2).

\section{RESULTS}

\section{Protease activity of krill homogenate}

Protease activities of the homogenates obtained at $\mathrm{pH} 5.0$ and 8.0 (see Methods) were determined at $\mathrm{pH} 5.0$ and 8.0 , respectively. The activities were investigated using $Z$ Phe-Ala, Z-Glu-Tyr, Hipp-Arg, Hipp-Phe, BzArg-pNA and Leu-pNA, as shown in Table I. At pH 5.0, Z-Phe-Ala, Z-Glu-Tyr and HippPhe were considerably hydrolyzed, but activities for Hipp-Arg and Bz-Arg-pNA was not detected. At $\mathrm{pH}$ 8.0, Z-Glu-Tyr, Hipp-Phe, Hipp-Arg and Bz-Arg-pNA were remarkably
Table I. Protease Activity of Krill Homogenates on VARIOUS SUbSTRATES

Protease activities of the homogenates obtained at $\mathrm{pH}$ 5.0 and 8.0 were determined at $\mathrm{pH} 5.0$ and 8.0 , respectively, as described in METHODS.

\begin{tabular}{lcc}
\hline & \multicolumn{2}{c}{ Activity $(\mu \mathrm{mol} / \mathrm{min} / 100 \mathrm{~g}$ tissue $)$} \\
\cline { 2 - 3 } Substrates & at pH 5.0 & at $\mathrm{pH} 8.0$ \\
\hline Z-Phe-Ala & 78.4 & $\mathrm{nd}^{a}$ \\
Z-Glu-Tyr & 78.4 & 31.4 \\
Hipp-Phe & 85.5 & 39.4 \\
Hipp-Arg & $\mathrm{nd}$ & 49.0 \\
Bz-Arg-pNA & $\mathrm{nd}$ & 10.2 \\
Leu-pNA & 1.4 & 4.4 \\
\hline
\end{tabular}

a nd, not detected under the experimental conditions.

hydrolyzed, but activity for Z-Phe-Ala which was detected at pH 5.0 was not observed. Low activity for Leu-pNA was found at both pHs. These results suggest that the homogenate of krill contains many types of exo- and endo-peptidases.

\section{Gel filtration of crude extracts on Sephadex $G$ - 150}

The present experiments were carried out to resolve the protease activities of the krill homogenate on the basis of the molecular size. The crude extract used for the present gel filtration was obtained after ammonium sulfate treatment of the homogenate (see Methods). Figure 1 shows the elution pattern of protease activities of the crude extracts at pH 8.0. Z-Phe-Ala hydrolyzing activity was eluted in two peaks (MW, 100,000 and $38,000)$. The hydrolase activities on Z-Glu-Tyr and Hipp-Phe eluted as one peak at the same position (MW, 35,000). Both ${ }^{14} \mathrm{C}-\mathrm{Hb}$ and $\mathrm{Bz}-$ Arg-pNA hydrolase activities were detected as a relatively broad peak ( $\mathrm{MW}, 33,000)$. The positions of Leu-pNA and Hipp-Arg hydrolase activities were MW, 130,000 and 32,000 , respectively. From the elution profiles of the hydrolase activities for various substrates, the existence of, at least, six kinds of proteases in the homogenate at $\mathrm{pH} 8.0$ was found.

Figure 2 shows the elution patterns of pro- 


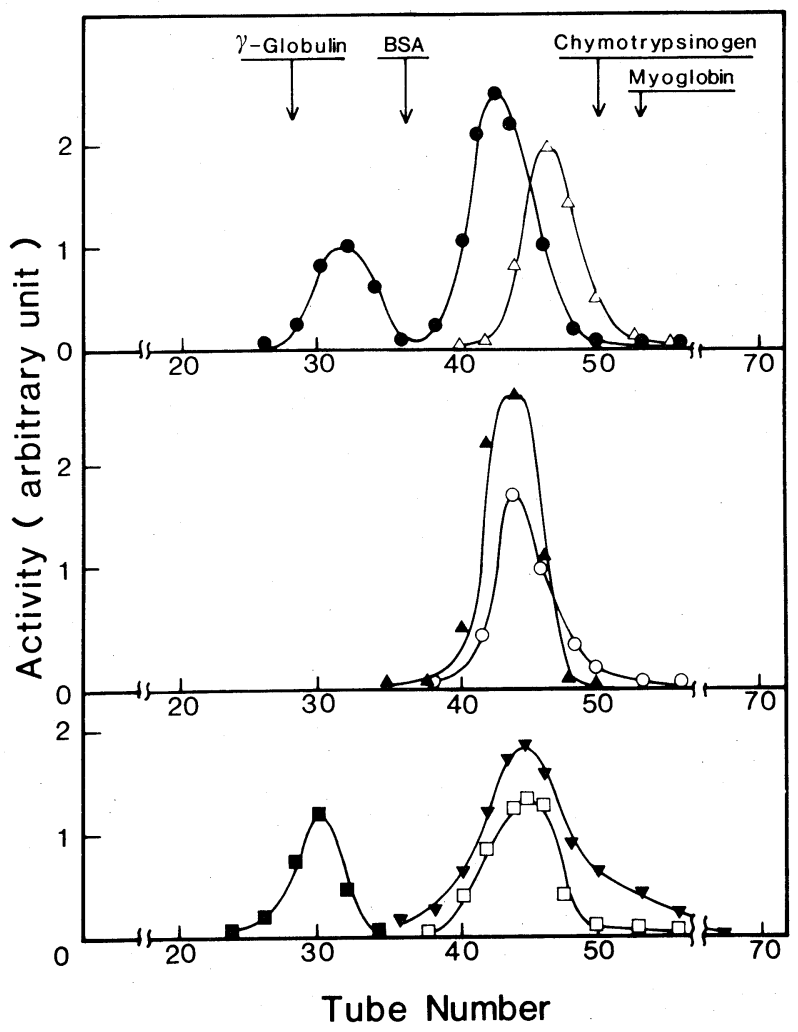

Fig. 1. Gel Filtration of the Krill Crude Extract at pH 8.0 on Sephadex G-150.

The concentrate of the crude extract at pH $8.0(2 \mathrm{ml})$ was applied to a Sephadex G-150 column $(2.5 \times 100 \mathrm{~cm})$ equilibrated with $0.1 \mathrm{M}$ Tris- $\mathrm{HCl}$ buffer, $\mathrm{pH} 8.0$, containing $0.1 \mathrm{M} \mathrm{KCl}$. Fractions of $2 \mathrm{ml}$ were collected. The main peak of each protease activity was subjected to isoelectric focusing and an inhibitory experiment (Table II). $\gamma$-globulin (MW, 150,000), BSA (MW, 66,300), chymotrypsinogen (MW, 25,700) and myoglobin (MW, 16,900) were used as MW markers. - - Z-Phe-Ala hydrolase activity; $\bigcirc-\bigcirc$, Z-Glu-Tyr hydrolase activity; $\boldsymbol{\Delta}-\boldsymbol{\Delta}$, Hipp-Phe hydrolase activity; $\triangle-\triangle$, Hipp-Arg hydrolase activity; $\mathbf{\square}-\mathbf{\square}$, Leu-pNA hydrolase activity; $\square-\square$, Bz-Arg-pNA hydrolase activity; $\nabla-\nabla,{ }^{14} \mathrm{C}$ - $\mathrm{Hb}$ hydrolase activity.

tease activities of the crude extracts at $\mathrm{pH}$ 5.0. Leu-pNA, Z-Phe-Ala and Hipp-Phe hydrolase activities eluted as a single peak at the positions of MW of 130,000, 60,000 and 25,000, respectively. Z-Glu-Tyr hydrolase activity eluted as two peaks (MW of 60,000 (the same as Z-Phe-Ala hydrolase activity) and 25,000 (the same as Hipp-Phe hydrolase activity)). ${ }^{14} \mathrm{C}-\mathrm{Hb}$ hydrolase activity showed a very broad distribution. These results indicate that, at least, four kinds of proteases are present in the homogenate at $\mathrm{pH}$ 5.0.

Isoelectric focusing of the active fraction from gel filtration

Each fraction from the gel filtrations at $\mathrm{pH}$
8.0 and 5.0 (Figs. 1, 2) were collected and subjected to isoelectric focusing ( $\mathrm{pH} 3 \sim 10)$. Figure 3 shows the isoelectric focusing pattern of the active fractions at $\mathrm{pH}$ 5.0. The $\mathrm{pI}$ value for each substrate was as follows: 4.8 for ZPhe-Ala, 3.6 and 4.8 for Z-Glu-Tyr, 3.6 for Hipp-Phe and ${ }^{14} \mathrm{C}-\mathrm{Hb}$, and 4.5 for Leu-pNA. Isoelectric focusing of the active fractions at $\mathrm{pH} 8.0$ was also carried out, it was found that the only Leu-pNA hydrolase activity was focused at the position of pI 4.9. However, the other hydrolase activities were not clearly focused in the column, because some precipitation occurred near the anodic electrode solution. 


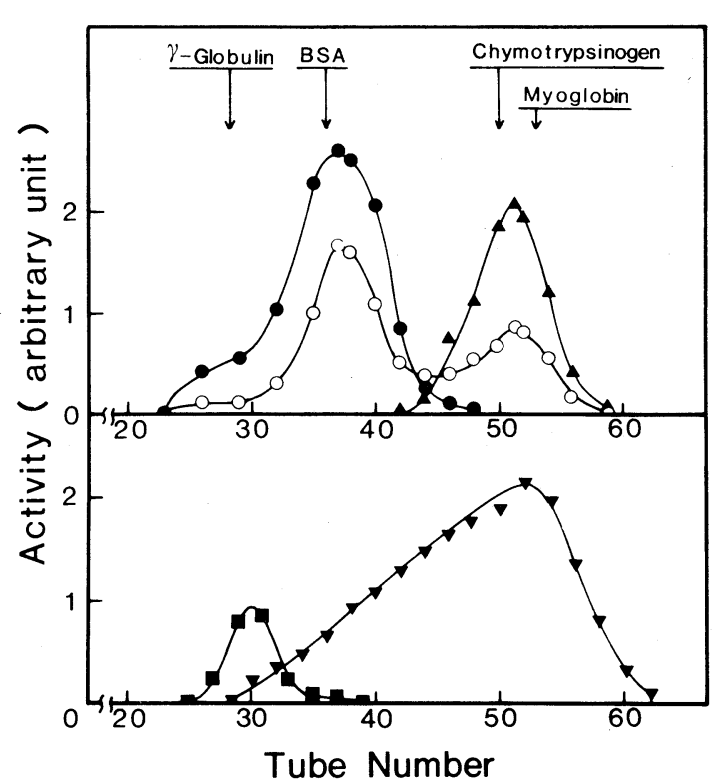

FIG. 2. Gel Filtration of the Krill Crude Extract at $\mathrm{pH}$ 5.0 on Sephadex G-150.

The concentrate of the crude extract at pH $5.0(2 \mathrm{ml})$ was applied to a Sephadex G-150 column $(2.5 \times 100 \mathrm{~cm})$ equilibrated with $0.1 \mathrm{M}$ acetate buffer, $\mathrm{pH} 5.0$, containing $0.6 \mathrm{M} \mathrm{KCl}$. The volume of fractions and MW markers were the same as those in Fig. 1. The main peak of each protease activity was subjected to isoelectric focusing (Fig. 3) and an inhibitory experiment (Table III). - $-\mathrm{Z}$ Phe-Ala hydrolase activity; $\bigcirc-\bigcirc, Z-G l u-T y r$ hydrolase activity; $\mathbf{\Delta}-\boldsymbol{\Delta}$, Hipp-Phe hydrolase activity; $\mathbf{\square}-\mathbf{\square}$, Leu-pNA hydrolase activity; $\boldsymbol{\nabla}-\boldsymbol{\nabla},{ }^{14} \mathrm{C}-\mathrm{Hb}$ hydrolase activity.

Effects of inhibitors on the protease activities of the active fraction from gel filtration

The effects of various inhibitors on the activities of the active fractions from gel filtration (Figs. 1, 2) were examined. The results at $\mathrm{pH} 8.0$ are given in Table II, Inhibitory patterns for the activities hydrolyzing Z-PheAla, Z-Glu-Tyr, Hipp-Phe and Leu-pNA were similar, indicating that only EDTA remarkably suppressed these activities. DFP and STI were powerful inhibitors for Bz-Arg-pNA hydrolase. Hipp-Arg hydrolase activity was inhibited by EDTA and STI. ${ }^{14} \mathrm{C}-\mathrm{Hb}$ hydrolase activity was suppressed by DFP, EDTA and STI.

The results at $\mathrm{pH}$ 5.0, which were different from those at $\mathrm{pH} 8.0$, are shown in Table III.
Z-Phe-Ala hydrolase was strongly inhibited by DFP. Z-Glu-Tyr hydrolases, high MW and low MW types, showed different inhibitory profiles. The former was strongly inhibited only by DFP, and the latter only by EDTA. The activities hydrolyzing Hipp-Phe and LeupNA were suppressed only by EDTA. From the results of inhibitory experiments, the protease activities at $\mathrm{pH} 8.0$ and 5.0 could be classified into four and three groups, respectively.

\section{DISCUSSION}

The $\mathrm{pH}$ of the krill homogenate was $7 \sim 8$ and it dropped to the weak acidic range with the progress of autolysis. In the previous paper, ${ }^{10)}$ we reported that proteolysis of the krill proteins was extensive in the $\mathrm{pH}$ range of from 4 to 10 . Therefore, in the present experiments, we examined the kinds of proteases which were reactive at $\mathrm{pH} 5.0$ and 8.0 . The substrate specificities, molecular weights, isoelectric points and sensitivities to inhibitors of the present proteases examined are summarized in Table IV.

The proteases acting at $\mathrm{pH} 8.0$ could be classified into the following groups: Cpase A type (E-I, II, III) ${ }^{23)}$ Cpase B type (E-IV), ${ }^{24)}$ trypsin type $(\mathrm{E}-\mathrm{V})^{25)}$ and aminopeptidase (EVI). ${ }^{26,27)}$ Among them, the Cpase A type consisted of three species (Z-Phe-Ala hydrolase, MW, 100,000 (E-I) and 38,000 (E-II), and Hipp-Phe hydrolase, MW, 35,000 (E-III), indicating that E-I is different from the usual hog or cow Cpase A (MW, about 35,000) in terms of $\mathrm{MW}^{23)}$ These Z-Phe-Ala hydrolase activities were definitely detected in the fractions after gel filtration, in spite of not being found in the crude homogenate at $\mathrm{pH} 8.0$ (Table I). This observation could be explained by that an inhibitor for these hydrolases was removed from the crude homogenate through the gel filtration process. Hipp-Arg hydrolase (E-IV), which is the Cpase B type, was partially inhibited by STI without complete inhibition by EDTA. The partial inhibition of the Cpase B activity by STI is not clear. 


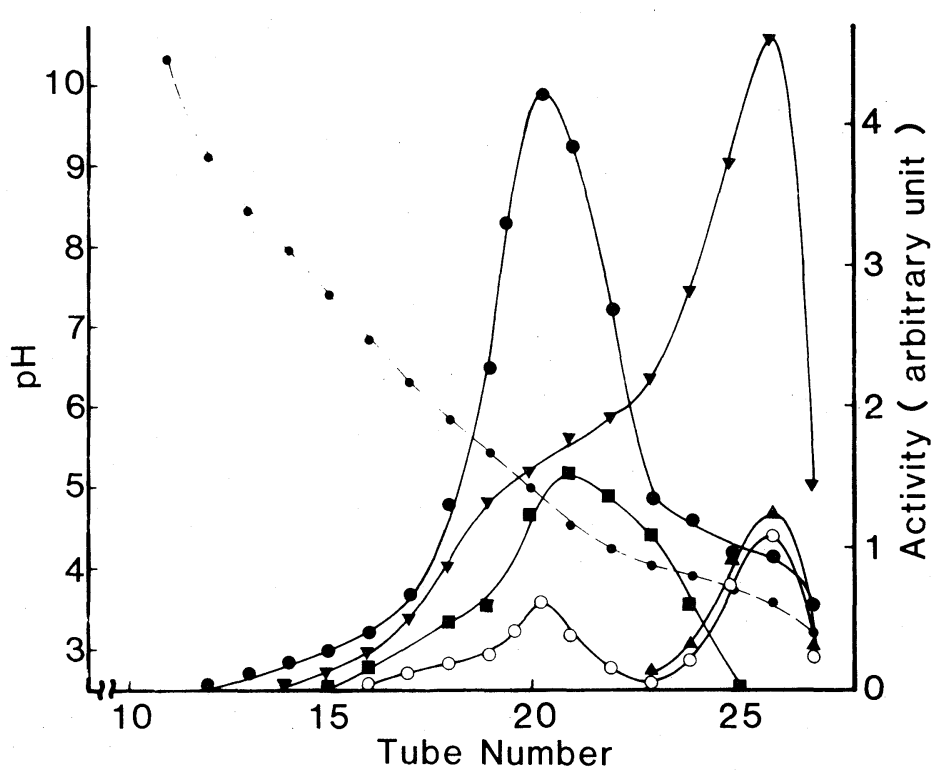

FIG. 3. Isoelectric Focusing of the Active Fraction from Gel Filtration on Sephadex G-150 at pH 5.0.

Column isoelectric focusing in a sucrose gradient was performed according to the method of Vesterberg and Svensson $^{30)}$ with a column volume of $110 \mathrm{ml}$ using ampholine (pH $3 \sim 10$ ). The main peak in Fig. 2 was applied to the column. Electrophoresis was carried out at $200 \mathrm{~V}$ for $8 \mathrm{hr}$, followed by at $800 \mathrm{~V}$ for $48 \mathrm{hr}$ at $4^{\circ} \mathrm{C}$. The column for fractionation was $1 \mathrm{ml}$. - , Z-Phe-Ala hydrolase activity; $\bigcirc-\bigcirc$, Z-Glu-Tyr hydrolase activity; $\mathbf{\Delta}-\mathbf{\Delta}$, Hipp-Phe hydrolase activity; $-\mathbf{\square}$, Leu-pNA hydrolase activity; $\boldsymbol{\nabla}-\boldsymbol{\nabla},{ }^{14} \mathrm{C}-\mathrm{Hb}$ hydrolase activity; --- $\mathrm{pH}$.

Table II. Effects of Inhibitors on the Protease Activities of the Active Fractions from Gel Filtration on Sephadex G-150 at pH 8.0

The main peak of each active fraction (Fig. 1) was used for the experiment. Each inhibitor was preincubated with the enzyme solution at $0^{\circ} \mathrm{C}$ for $60 \mathrm{~min}$. The enzyme reaction and the assay were carried out as described in METHODS.

\begin{tabular}{|c|c|c|c|c|c|c|c|c|c|}
\hline \multirow{2}{*}{\multicolumn{2}{|c|}{ Inhibitors (concn.) }} & \multicolumn{8}{|c|}{ Relative activity ( $\%$ ) } \\
\hline & & \multicolumn{8}{|c|}{ Substrates } \\
\hline & & \multicolumn{2}{|c|}{ Z-Phe-Ala } & \multirow{2}{*}{ Z-Glu-Tyr } & \multirow{2}{*}{ Hipp-Phe } & \multirow{2}{*}{ Hipp-Arg } & \multirow{2}{*}{\multicolumn{2}{|c|}{ Bz-Arg-pNA Leu-pNA }} & \multirow{2}{*}{${ }^{14} \mathrm{C}-\mathrm{Hb}$} \\
\hline & & $\operatorname{High}^{a}$ & Low $^{a}$ & & & & & & \\
\hline None & & 100 & 100 & 100 & 100 & 100 & 100 & 100 & 100 \\
\hline DFP & $(1 \mathrm{~mm})$ & 95 & 99 & 84 & 98 & 108 & 7 & 104 & 30 \\
\hline Pepstatin & $(1.5 \mu \mathrm{M})$ & 99 & 99 & 106 & 105 & 102 & 100 & 99 & 108 \\
\hline IAA & $(1 \mathrm{~mm})$ & 105 & 99 & 102 & 98 & 101 & 110 & 96 & 110 \\
\hline EDTA & $(1 \mathrm{~mm})$ & 35 & 31 & 31 & 23 & 35 & 10 & 31 & 44 \\
\hline STI & $(0.05 \%)$ & 101 & 94 & 94 & 104 & 41 & 5 & 95 & 13 \\
\hline
\end{tabular}

a High, active fraction of MW, 100,000. Low, active fraction of MW, 38,000.

The proteases acting at $\mathrm{pH} 5.0$ could be classified into the following groups: Cathepsin A type (E-VII), ${ }^{28)}$ Cpase A type (E-VIII), ${ }^{23)}$ aminopeptidase type $(\mathrm{E}-\mathrm{IX})^{26,27)}$ and trypsin type $(\mathrm{E}-\mathrm{X}){ }^{25}{ }^{25}$ The Hipp-Phe or Z-Glu-Tyr hydrolase (E-VIII) was grouped into the Cpase A type in terms of substrate specificity and the inhibitor response may be different from the 
Table III. Effects of Inhibitors on the Protease Activities of the Active Fractions from Gel Filtration ON SEPhadex G-150 at pH 5.0

The main peak of each active fraction (Fig. 2) was used for the experiment. The experimental conditions were the same as those in Table II.

\begin{tabular}{|c|c|c|c|c|c|c|c|}
\hline \multirow{4}{*}{ Inhibitors } & \multirow{4}{*}{ (concn.) } & \multicolumn{6}{|c|}{ Relative activity $(\%)$} \\
\hline & & \multicolumn{6}{|c|}{ Substrates } \\
\hline & & \multirow{2}{*}{ Z-Phe-Ala } & \multicolumn{2}{|c|}{ Z-Glu-Tyr } & \multirow{2}{*}{ Hipp-Phe } & \multirow{2}{*}{ Leu-pNA } & \multirow{2}{*}{${ }^{14} \mathrm{C}-\mathrm{Hb}$} \\
\hline & & & $\operatorname{High}^{a}$ & Low $^{a}$ & & & \\
\hline None & & 100 & 100 & 100 & 100 & 100 & 100 \\
\hline DFP & (1 mM) & 10 & 14 & 96 & 101 & 90 & 49 \\
\hline Pepstatin & $(1.5 \mu \mathrm{M})$ & 107 & 98 & 99 & 103 & 99 & 109 \\
\hline IAA & $(1 \mathrm{mM})$ & 97 & 75 & 101 & 103 & 97 & 83 \\
\hline EDTA & $(1 \mathrm{~mm})$ & 107 & 96 & 4 & 2 & 14 & 104 \\
\hline STI & $(0.05 \%)$ & 114 & 104 & 100 & 105 & 99 & 41 \\
\hline
\end{tabular}

a High, active fraction of MW, 60,000. Low, active fraction of MW, 25,000.

Table IV. Classification of Krill Proteases

pH 8.0

\begin{tabular}{|c|c|c|c|c|c|}
\hline No. & Substrates & MW & $\mathrm{pI}$ & Inhibitors & Remarks \\
\hline E-I & & $100 \mathrm{~K}$ & - & EDTA & \multirow{4}{*}{ Cpase A type ${ }^{23)}$} \\
\hline E-II & Z-Phe-Ala & $38 \mathrm{~K}$ & - & EDTA & \\
\hline E-III & Z-Glu-Tyr & $35 \mathrm{~K}$ & - & EDTA & \\
\hline E-III & Hipp-Phe & $35 \mathrm{~K}$ & - & EDTA & \\
\hline E-IV & Hipp-Arg & $32 \mathrm{~K}$ & - & EDTA, STI $^{a}$ & Cpase B type ${ }^{24)}$ \\
\hline $\mathrm{E}-\mathrm{V}$ & ${ }^{14} \mathrm{C}-\mathrm{Hb}$ & $33 \mathrm{~K}$ & - & DFP, STI & \multirow{2}{*}{ Trypsin type $\mathrm{e}^{25)}$} \\
\hline E-V & Bz-Arg-pNA & $33 \mathrm{~K}$ & - & DFP, STI & \\
\hline E-VI & Leu-pNA & $130 \mathrm{~K}$ & 4.9 & EDTA & Aminopeptidase type $\mathrm{e}^{26,27)}$ \\
\hline
\end{tabular}

pH 5.0

\begin{tabular}{|c|c|c|c|c|c|}
\hline E-VII & Z-Phe-Ala & $60 \mathrm{~K}$ & 4.8 & DFP & Cathepsin A type ${ }^{28)}$ \\
\hline E-VII & 7-Glu-Tyr & $60 \mathrm{~K}$ & 4.8 & DEP & \\
\hline E-VIII & Z-Giu- Iyr & $25 \mathrm{~K}$ & 3.6 & EDTA & \multirow[t]{2}{*}{ Cpase A type ${ }^{23)}$} \\
\hline E-VIII & Hipp-Phe & $25 \mathrm{~K}$ & 3.6 & EDTA & \\
\hline E-IX & Leu-pNA & $130 \mathrm{~K}$ & 4.5 & EDTA & Aminopeptidase type $\mathrm{e}^{26,27)}$ \\
\hline E-X & ${ }^{14} \mathrm{C}-\mathrm{Hb}$ & - & 3.6 & $\begin{array}{l}\mathrm{DFP}_{,}^{a}{ }^{a} \mathrm{STI}^{a} \\
\mathrm{IAA}^{a}\end{array}$ & Several types \\
\hline
\end{tabular}

a Partially inhibited.

usual Cpase A type (E-II, III) described above, since the specific activity of Hipp-Phe hydrolase at $\mathrm{pH} 5.0$ was higher than that at $\mathrm{pH}$ 8.0 (Table I) and the MW of E-VIII was different from those of E-II and E-III. The ${ }^{14} \mathrm{C}-\mathrm{Hb}$ hydrolase fraction (E-X) may be a mixture of proteases including trypsin type (inhibition by both DFP and STI) and cathepsin
B type ${ }^{29)}$ (inhibition by IAA) proteases. In this fraction, however, the cathepsin D type of protease, which is a typical endoprotease of the lysosome, was not found, because of no inhibition of the ${ }^{14} \mathrm{C}-\mathrm{Hb}$ hydrolase activity by pepstatin (Table III).

In this study, we first detected the Cpase B and aminopeptidase types of proteases in 
Antarctic krill, but could not find acid proteases such as those reported by Kimoto et $a l .{ }^{16)}$ There are several reports regarding trypsin type proteases. ${ }^{11,13 \sim 15,17)}$ This type of protease in this study seems to be the same type of proteases as that described above. Chen et $a .^{14)}$ reported the existence of the Cpase A type of protease having a molecular weight of 24,000 and an optimum $\mathrm{pH}$ of 9.0. We detected three kinds of Cpase A type proteases in terms of molecular weight $(100,000,38,000$, $35,000)$, suggesting that the present proteases are different from that seen by Chen et al.

From all the results described above, we suppose that the actions of Cpase A and B, aminopeptidase, trypsin and cathepsin $\mathrm{A}$ and B types of proteases are responsible for the autolysis of krill proteins in the process after thawing of the frozen krill. However, it is not clear which proteases are mainly responsible for the autolysis of krill proteins. An investigation concerning this problem is in progress.

Acknowledgment. The authors wish to thank the Central Research Institute, Nippon Suisan Co., Ltd., for kindly supplying the Antarctic krill used in this study.

\section{REFERENCES}

1) P. R. Burkholder, E. F. Mandelli and P. Centeno, $J$. Agric. Food Chem., 15, 718 (1967).

2) G. S. Sidhu, W. A. Montgomery, G. L. Holloway, A. R. Johnson and D. M. Walker, J. Sci. Food Agric., 21, 293 (1970).

3) T. Kinumaki, Shoku no Kagaku, 11, 74 (1973).

4) M. Yanase, New Food Ind., 16, 6 (1974).

5) S. Kimura, Kagaku to Seibutsu, 13, 432 (1975).

6) K. Arai, T. Watanabe and T. Kinumaki, Bull. Tokai Reg. Fish. Res. Lab., No. 85, 1 (1976).

7) K. Kuwano, Y. Osawa, N. Sekiya, A. Tukui and T. Mitamura, Eiyo to Shokuryo, 28, 191 (1975).
8) K. Kuwano, Y. Osawa, N. Sekiya, A. Tukui and T. Mitamura, Eiyo to Shokuryo, 29, 35 (1976).

9) M. Kubota and K. Sakai, J. Tokyo Univ. Fish., 2, 53 (1978)

10) Y. Kawamura, K. Nishimura, S. Igarashi, E. Doi and D. Yonezawa, Agric. Biol. Chem., 45, 93 (1981).

11) A. Noguchi, M. Yanagimoto, K. Umeda and S. Kimura, Nippon Nôgeikagaku Kaishi, 50, 415 (1976).

12) E. Nagahisa, S. Nishimuro and M. Mori, Rep. Central Res. Lab. Nippon Suisan Co., Ltd., 11, 6 (1976).

13) N. Seki, H. Sakaya and T. Onozawa, Bull. Jpn. Soc. Scient. Fish., 43, 955 (1977).

14) C. S. Chen, T. R. Yan and H. Y. Chen, J. Food Biochem., 2, 349 (1978).

15) S. Konagaya, Bull, Jpn. Soc. Scient. Fish., 46, 175 (1980).

16) S. Kimoto, V. V. Thanh and K. Murakami, J. Food Sci., 46, 1881 (1981).

17) K. Kimoto, S. Kusama and K. Murakami, Agric. Biol. Chem., 47, 529 (1983).

18) J. C. Sheehan and G. P. Hess, J. Am. Chem. Soc., 77, 1067 (1951).

19) H. R. Williams and T. Y. Lin, Biochim. Biophys. Acta, 250, 603 (1971).

20) S. Moore and W. H. Stein, J. Biol. Chem., 211, 907 (1954).

21) C. W. Ward, Anal. Biochem., 56, 596 (1973).

22) O. H. Lowry, N. J. Rosebrough, A. L. Farr and R. J. Randall, J. Biol. Chem., 193, 265 (1951).

23) P. H. Petra, Methods Enzymol., 19, 460 (1970).

24) J. E. Folk, Methods Enzymol., 19, 504 (1970).

25) B. Kell, “The Enzyme," Vol. III, ed. by P. D. Boyer, Academic Press, New York, 1971, p. 250.

26) S. R. Himmelhoch, Methods Enzymol., 19, 508 (1970).

27) G. Peleiderer, Methods Enzymol., 19, 514 (1970).

28) J. K. McDonald and C. Schwabe, "Proteinases in Mammalian Cells and Tissues," ed. by A. J. Barrett, North-Holland Publishing Company, Amsterdam, 1977, p. 311.

29) A. J. Barrett, "Proteinases in Mammalian Cells and Tissues," ed. by A. J. Barrett, North-Holland Publishing Company, Amsterdam, 1977, p. 181.

30) O. Vesterberg and H. Svensson, Acta Chem. Scand., 20, 820 (1966). 